\title{
MENGENAL BANK "SYARIAH" LEMBAGA KEUANGAN UNTUK UMUM
}

\author{
Fauzi Solihin ${ }^{1}$
}

\begin{abstract}
The article objective is to compare Syariah banking system to common banking system. It is concluded that Syariah banking system can be alternative banking system to any body who expect profit sharing as the replacement of common interest mechanism.
\end{abstract}

Keywords: Syariah Bank

\section{ABSTRAK}

Artikel bertujuan membandingkan bank Syariah dengan bank umum. Disimpulkan bahwa sistem bank Syariah dapat menjadi suatu alternatif pengembangan usaha dengan cara pembagian laba sebagai pengganti mekanisasi bunga perbankan.

Kata kunci: Bank Syariah

\footnotetext{
${ }^{1}$ Staf Pengajar STIE Swadaya \& Fakultas Ekonomi, UBiNus, Jakarta
} 


\section{PENDAHULUAN}

Sebagaimana bank pada umumnya, Bank Syariah merupakan lembaga keuangan yang usaha pokoknya menyalurkan pembiayaan dan memberikan jasa lalu lintas pembayaran serta peredaran uang namun pengoperasiannya disesuaikan dengan prinsip prinsip syariat Islam.

Perbedaan pokok antara perbankan Syariah dengan perbankan konvensional adalah adanya larangan riba (bunga) bagi perbankan Syariah sedangkan jual beli (bali') dihalalkan. Dalam pandangan Islam uang hanya sebagai alat tukar dan bukan suatu komoditas karena Islam tidak mengenal "time value of money". Dengan demikian, dilarang untuk membayar atau menerima bunga dari uang yang dipinjamkan. Sebagai pengganti mekanisme bunga, bank Syariah melakukan bagi hasil (profit sharing).

\section{PEMBAHASAN}

\section{Sejarah Bank Syariah di Indonesia}

Bank umum pertama di Indonesia yang beroperasi berdasarkan syariat Islam adalah PT Bank Muamalat Indonesia Tbk sesuai Undang-Undang No.7 tahun 1992 tentang perbankan yang secara tegas mengatur ketentuan bank berdasarkan prinsip syariah Islam.

Dalam dua tahun terakhir, beberapa bank pemerintah maupun bank swasta mulai beroperasi sebagai bank Komersial Syariah atau hanya membentuk Unit Bank Syariah. Sampai dengan akhir tahun 2001, jaringan bank Syariah di Indonesia terdiri dari berikut ini.

\begin{tabular}{lcccc}
\hline Kelompok & KP/UBS & KC/KPO & KCP & KK \\
\hline Bank Komersial Syariah & 2 & 35 & 4 & 44 \\
1. Bank Muamalat & 1 & 12 & 4 & 38 \\
Indonesia & 1 & 23 & 0 & 6 \\
2. Bank Syariah & 3 & 12 & 0 & 0 \\
$\quad$ Mandiri & 1 & 1 & 0 & 0 \\
Unit Bank Syariah : & 1 & 10 & 0 & 0 \\
1. Bank IFI & 1 & 1 & 0 & 0 \\
2. Bank & 81 & 0 & 0 & 0 \\
Indonesia & & & & \\
3. Negara & & & & \\
BPR Syariah Jabar & 86 & 47 & 4 & \\
\hline
\end{tabular}

Keterangan:

KP/UBS = Kantor Pusat / Unit Bank Syariah

$\mathrm{KC} / \mathrm{KPO}=$ Kantor Cabang $/$ Kantor Pusat Operasional

$\mathrm{KCP}=$ Kantor Cabang Pembantu

KK $\quad=$ Kantor Kas

Sumber: Bank Indonesia 


\section{Tujuan Bank Syariah}

1. Mengarahkan kegiatan ekonomi umat untuk bermuamalah/beraktifitas secara Islami khususnya muamalah yang berhubungan dengan perbankan agar terhindar dari praktik riba atau jenis usaha/perdagangan lain yang mengandung unsur penipuan.

2. Untuk menciptakan suatu keadilan di bidang ekonomi dengan jalan meratakan pendapatan melalui kegiatan investasi sehingga tidak terjadi kesenjangan yang amat besar antara pemilik modal dengan pihak yang membutuhkan dana.

3. Untuk meningkatkan kualitas hidup umat, dengan jalan membuka peluang berusaha yang lebih besar.

4. Untuk menjaga kestabilan ekonomi moneter, melalui aktifitas bank Islam yang diharapkan mampu menghindari inflasi dan negative-spread akibat penerapan sistem bunga.

5. Menghindari persaingan yang tidak sehat antara lembaga keuangan khususnya bank, serta menanggulangi kemandirian lembaga keuangan dari pengaruh gejolak moneter baik di dalam maupun luar negeri.

\section{Ciri Bank Syariah}

1. Bagi hasil dan keuntungan yang disepakati bersama pada waktu akad perjanjian diwujudkan dalam bentuk persentase bagi hasil dari jumlah keuntungan yang besarnya tidak kaku dan dapat dilakukan dengan kebebasan untuk melakukan tawar-menawar dalam batas wajar.

2. Penggunaan presentase tetap dari jumlah kewajiban untuk melakukan pembayaran selalu dihindarkan karena presentase bersifat melekat pada sisa hutang meskipun batas perjanjian telah berakhir. Sistem presentase memungkinkan beban bunga semakin tinggi.

3. Dalam kontrak pembiayaan proyek, Bank Syariah tidak menerapkan perhitungan berdasarkan nominal pembiayaan (fixed return) yang ditetapkan dimuka karena pada hakikatnya untung/ ruginya suatu proyek yang dibiayai bank baru diketahui setelah proyek itu selesai.

4. Adanya Dewan Pengawas Syariah yang bertugas mengawasi operasional bank dari sudut syariah (Hukum Islam)

5. Ada produk khusus yang tidak terdapat dalam bank konvensional, yaitu pembiayaan tanpa beban yang murni bersifat sosial. Produk itu ditujukan bagi orang miskin/sangat membutuhkan untuk kegiatan keagamaan. Sumber dana fasilitas ini berasal dari zakat, infak sedeqah, dan pendapatan nonhalal sebagai hasil transaksi dengan bank konvensional yang menetapkan sistem bunga. 


\section{Keistimewaan Bank Syariah}

1. Kesamaan ikatan emosional yang kuat antara pengelola bank dengan nasabah sehingga dalam menghadapi risiko usaha membagi keuntungan secara jujur dan adil.

2. Diterapkannya prinsip bagi hasil sebagai pengganti bunga.

3. Konsep Bank Syariah berorientasi pada kebersamaan dalam hal berikut.

a. Mendorong investasi dan menghambat simpanan yang tidak produktif melalui profit and loss sharing;

b. memerangi kemiskinan dengan membina ekonomi lemah melalui bantuan hibah yang diarahkan secara produktif;

c. meratakan pendapatan melalui sistem bagi hasil baik yang diberlakukan kepada bank (Mudharib) atau kepada pemegang amanah maupun kepada peminjam.

\section{Perbedaan Bank Syariah dengan Bank Konvensional}

\section{Sistem Bagi Hasil}

1. Penentuan besarnya risiko dibuat pada waktu akad dengan berpedoman pada kemungkinan untung rugi.

2. Besarnya rasio bagi hasil didasarkan pada jumlah keuntungan yang diperoleh.

3. Jumlah pembagian bagi hasil meningkat sesuai kenaikan jumlah keuntungan.

4. Tidak ada yang meragukan keuntungan bagi-hasil.

5. Kerugian akan ditanggung bersama oleh kedua pihak terkait.

\section{Sistem Bunga}

1. Penentuan dibuat pada waktu akad atas dasar proyeksi selalu untung.

2. Besarnya bunga tergantung pada jumlah modal yang dipinjam.

3. Besarnya bunga tidak terkait dengan tingkat keuntungan usaha.

4. Eksistensi bunga diragukan oleh semua agama termasuk Islam.

5. Bunga tetap dibayar meskipun usaha dalam keadaan rugi.

\section{Akad (perjanjian) Disesuaikan dengan Prinsip Produk Syariah yang Dipakai}

Misalnya, produk tabungan dapat saja menggunakan prinsip Mudharabah (tidak dapat ditarik kembali untuk jangka waktu tertentu dan pendapatan dalam bentuk bagi hasil) atau menggunakan prinsip Wadiah (tabungan yang dapat ditarik sewaktu-waktu dan penabung hanya mendapatkan bonus yang sifatnya tidak mengikat.

\section{Produk yang Dihasilkan}

Produk Bank Syariah cukup luas bahkan ada produk yang tidak lazim diterapkan pada bank konvensonal, misalnya Gadai (Rahn) dan Sewa/Leasing (Ijarah). 


\section{Konsep Syariah dalam Pendanaan}

1. Mudharabah

Kerja sama antara pemilik dana (Shahibul Maal) dengan pengelola dana dan keuntungan dibagi menurut kesepakatan.

2. Wadiah

Merupakan dana titipan nasabah kepada bank dan nasabah dapat menarik kembali kapan saja dikehendaki namun keuntungan menjadi hak pihak bank. Akan tetapi, bank dapat memberikan insentif atau bonus yang besarnya ditetapkan pihak bank.

Jenis Wadiah sebagai berikut.

a. Wadiah Yad Amanah

Barang atau dana titipan tidak dapat dimanfaatkan oleh bank dan bank tidak bertanggung jawab terhadap kerusakan yang mungkin terjadi.

b. Wadiah Yad Dhamanah

Pihak bank, baik dengan atau tanpa izin, dapat memanfaatkan dana titipan untuk dikelola sehingga menghasilkan keuntungan yang akan menjadi milik bank namun bank dapat memberikan insentif kepada nasabah.

\section{Konsep Syariah dalam Produk Pembiayaan}

1. Mudaharabah

Kerja sama antara pemilik modal (Shahibul Maal) dengan pengelola dana (Mudharib) dan hanya boleh menggunakan modal yang diberikan untuk melaksanakan proyek yang telah ditentukan dan pembagian hasil keuntungan sesuai nisbah yang telah disepakati.

\section{Murabahah}

Perjanjian antara bank dengan nasabah, yakni bank Syariah menyediakan pembiayaan untuk bahan baku dan modal kerja lainnya yang dibutuhkan yang akan dibayar kembali oleh nasabah sebesar harga jual bank (harga beli bank ditambah margin keuntungan yang disepakati bersama pada saat jatuh tempo). Pembayaran dilakukan dengan cara mengangsur selama jangka waktu yang telah ditentukan.

\section{Musyarakah}

Perjanjian antara bank dengan nasabah, yaitu pihak bank dan pengusaha secara bersama membiayai suatu usaha/proyek, mengelola bersama atau dengan salah satu pihak atas dasar prinsip bagi hasil sesuai dengan pernyataan. Pemilik dana dapat melakukan intervensi dalam manajemen proyek. Bila terjadi kerugian dibagi berdasarkan perbandingan modal yang diberikan.

Mengenal Bank “Syariah” Lembaga Keuangan... (Fa uzi Solihin) 


\section{Salam}

Pembiayaan jual beli, yakni bank memberikan dana lebih dulu terhadap barang (hasil pertanian) yang telah disepakati yang dihantarkan kemudian. Dalam transaksi ini terdapat kesepakatan antara 3 pihak terkait, yaitu bank, nasabah A (penjual), dan nasabah B (pembeli). Dengan demikian, bank melakukan 2 transaksi pada waktu bersamaan, yaitu pembelian dari nasabah A dan penjualan dengan nasabah $\mathrm{B}$.

\section{Istishna}

Perjanjian jual beli dan pihak bank membuatkan barang (men-subkan kepada pihak lain) yang dipesan oleh nasabah dengan kriteria tertentu seperti jenis, tipe/model, kualitas, dan jumlah barang. Setelah barang jadi, bank menjual barang tersebut kepada nasabah dengan kesepakatan yang telah ditentukan sebelumnya.

6. Ijarah

Perjanjian sewa antara bank selaku lessor dengan nasabah selaku lessee yang memberikan kesempatan kepada penyewa untuk memanfaatkan barang yang disewa dengan imbalan uang sewa sesuai perjanjian serta mengambalikannya kepada pemilik setelah jangka waktu perjanjian berakhir (operating lease); atau terjadi pemindahan hak milik pada akhir sewa angsuran (finance lease)

7. Rahn

Perjanjian penyerahan barang berharga sebagai agunan agar dipenuhinya suatu kewajiban kepada bank (gadai). Untuk kendaraan atau properti, cukup dengan menyerahkan bukti kepemilikannya (BPKB, Sertifikat).

\section{VII.Konsep Syariah dalam Jasa}

1. Kafalah

Merupakan pemberian garansi oleh pihak bank kepada nasabah untuk menjamin pelaksanaan proyek dan pemenuhan kewajiban tertentu kepada pihak yang dijamin

2. Wakalah

Perjanjian antara bank dengan nasabah untuk mentransfer dana dari nasabah kepada seseorang di tempat lain, termasuk juga mengeluarkan letter of credit.

\section{Hawalah}

Perjanjian pengalihan hak dan kewajiban nasabah pihak pertama (piutang) kepada bank sebagai pihak kedua dari nasabah lain pihak ketiga (berhutang). Bank melaksanakan pembayaran lebih dahulu atas transaksi yang timbul baik dari jual beli atau transaksi lainnya, setelah hutang piutang tersebut jatuh tempo maka pihak ketiga akan melakukan pembayaran kepada bank (Anjak piutang). 


\section{Sharf}

Sharf merupakan jual beli mata uang asing yang saling berbeda.

Dari uraian tersebut, Bank Syariah selalu menunjang sektor riil dan tidak ikut bermain dalam SBI (yang risikonya sangat minim) untuk mendapat margin/keuntungan sebagaimana yang dilakukan bank konvensional saat ini dengan memanfaatkan diskonto SBI yang masih tinggi.

Perbankan Syariah memang tidak diperkenankan bermain SBI maupun transaksi derivatif karena perbankan Syariah menekankan pada konsep bagi hasil (profit sharing) ketimbang konsep bunga (konsep keuangan kapitalis) yang digunakan bank konvensional.

Pada bank konvensional, bunga ditetapkan pada awal perjanjian (akad kredit) atas dasar proyeksi selalu untung. Suku bunga tidak terkait dengan tingkat keuntungan usaha bahkan bunga tetap dibebankan pada kondisi usaha rugi sehingga menimbulkan beban bunga berbunga sedangkan pada bank Syariah yang ditetapkan hanya nisbah atau rasio pembagian hasil keuntungan usaha.

Pada dasarnya, ada beberapa jenis sistem perhitungan bagi hasil yang digunakan bank Syariah, yaitu Profit /Loss Sharing dan Revenue Sharing. Perbedaan pokok antara kedua sistem tersebut sebagai berikut.

1. Profit/Loss Sharing, yakni besar/kecilnya pendapatan bagi hasil yang akan diterima nasabah tergantung dari besar/kecilnya keuntungan suatu bank.

2. Revenue Sharing adalah besar/kecilnya pendapatan bagi hasil yang akan diterima nasabah tergantung pada besar kecilnya pendapatan kotor suatu bank.

Kendala

Hambatan yang mungkin dirasakan hanyalah pada istilah yang digunakan lebih khas dan berbau "Arab”. Di sisi lain, telinga dan pikiran kita sudah terbiasa dengan istilah dalam bahasa Inggris atau Belanda sehingga istilah yang lazim digunakan dalam perbankan Syariah menjadi asing atau kurang familiar.

\section{PENUTUP}

\section{Simpulan}

Pada hakikatnya, transaksi atau aktifitas bank Syariah tidak banyak beda dengan apa yang dilakukan bank konvensional. Perbedaan pokok antara perbankan Syariah dengan perbankan konventional adalah konsep yang diletakkan sebagai dasar operasional bank. Dengan demikian, setiap orang atau siapa saja yang tidak menghendaki bunga dan menginginkan bagi hasil dapat menggunakan Bank Syariah sebagai sarananya. Jadi, bank Syariah bukan hanya untuk umat Muslim saja melainkan hanya suatu konsep keuangan/perbankan yang dilandaskan pada hukum (syariat) Islam. 


\section{DAFTAR PUSTAKA}

Antonio M., Syafii. Bank Syariah Bagi Bankir dan Praktisi Keuangan. Jakarta: BI \& Tazkia.

Arifin, Zainul. Memahami “Bank Syari’ah”. Alvabet Jakarta.

Suyatno, Thomas. Kelembagaan Perbankan. Jakarta: PT Gramedia.

Undang Undang No.7 tahun 1992 dan No.10 tahun 1998 tentang Perbankan.

\section{LAMPIRAN}

\section{Rumus perhitungan bagi hasil (dana)}

Saldo rata rata nasabah

- X Total Bagi Hasil X Nisbah Nasabah

Saldo rata rata produk

Contoh

- $\quad$ Saldo rata rata dana Simpanan/Tabungan Rp.5.000.000.000,-

- $\quad$ Nisbah bagi hasil: Bank (45\%), Nasabah (55\%)

- Distribusi pendapatan produk Simpanan/Tabungan Rp.75.000.000,-

- $\quad$ Saldo rekening seorang nasabah tercatat sebagai berikut.

\begin{tabular}{|c|c|c|}
\hline $\begin{array}{rc}\text { Tanggal: } & 1 \\
6 \\
21 \\
26 \\
\text { Rata rata }\end{array}$ & Saldo : & $\begin{array}{lr}\text { Rp. } & 2.000 .000,-- \\
\text { Rp. } 10.000 .000,-- & \\
\text { Rp. } 15.000 .000,-- \\
\text { Rp. } & 1.000 .000,-- \\
\text { Rp. } & 8.000 .000,--\end{array}$ \\
\hline
\end{tabular}

Bagi hasil yang diterima nasabah Rp. 8.000.000,-X Rp.75.000.000,-- X 55 \% = Rp. 66.000,-Rp.5.000.000.000,-- 


\section{Ringkasan produk Bank Syariah Vs Bank Konvensional}

a. Penghimpunan Dana

\begin{tabular}{lll}
\hline No & Syariah & Konvensional \\
\hline & & \\
1 & Wadi'ah Yad Dhamanah & Giro \\
2 & Wadi'ah Yad Dhamanah Mudharabah & Tabungan \\
3 & & Deposito \\
\hline
\end{tabular}

b. Penyaluran Dana dan Jasa

\begin{tabular}{lll}
\hline No & Syariah & Konvensional \\
\hline & & \\
1 & Qardh & Dana Talangan \\
2 & Musyarakah & Penyertaan \\
3 & Ijarah Wa Iqtina & Sewa Beli (Leasing) \\
4 & Mudharabah, Murabahah & Pembiayaan Modal Kerja \\
5 & Mudharabah atau Musyarakah & Pembiayaan Proyek \\
6 & Bai As Salam & Pembiayaan Pertanian \\
7 & IjarahMuntahuya Bittamlik & Akuisisi Asset \\
8 & Mudharabah / Murabahah & Pembiayaan Ekspor \\
9 & Hawalah & Anjak Piutang \\
10 & Wakalah & Letter of Credit (L/C) \\
11 & Kafalah & Garansi Bank \\
12 & Wakalah dan Hawalah & Inkasso / Transfer \\
13 & Qardhul Hasan & Pinjaman Sosial \\
14 & Qardh, Bai Al Dayan & Surat Berharga \\
15 & Wadi'ah Amanah & Safe Deposit Box \\
16 & Rahn & Gadai \\
17 & Sharf & Jual Beli Valuta Asing \\
& & \\
\hline
\end{tabular}

Mengenal Bank “Syariah" Lembaga Keuangan... (Fa uzi Solihin) 